\title{
PENGARUH SIKAP DAN MOTIVASI TERHADAP KINERJA KARYAWAN PADA MTsN TAKERAN KABUPATEN MAGETAN
}

\author{
Samsuri ${ }^{1)}$, Hari Purwanto ${ }^{2)}$ \\ ${ }^{1)}$ Mahasiswa Program Studi Manajemen, Fakultas Ekonomi dan Bisnis \\ Universitas PGRI Madiun \\ ${ }^{2)}$ Dosen Fakultas Ekonomi dan Bisnis Universitas PGRI Madiun
}

\begin{abstract}
The problems faced by MTsN Takeran Kab. Magetan is that employees often face problems in the workplace, either with colleagues, superiors or the job itself. The attitude of employees in response to the work environment will be able to affect the performance of employees. The attitude of the employee must be balanced high motivation to work so that the employee's performance can be maximized. The purpose of this study was to determine the effect of work attitudes and motivation on employee performance on MTsN Takeran Kab. Magetan. Based on calculations Regression Test SPPS program showed that the 21:00 version Attitude and Motivation significant and positive impact on employee performance. Thus, the higher or better attitude and motivation, the performance of employees will be increased.
\end{abstract}

Keywords: Attitude, Motivation and Employee Performance.

\section{PENDAHULUAN}

Meningkatkan kinerja karyawan dalam manajemen yang efektif memerlukan dukungan sumber daya manusia (SDM) yang cakap dan kompeten di bidangnya. Permasalahan Manajemen Sumber Daya Manusia di dalam perusahaan selalu dihadapkan kepada kompleksitas pemenuhan antara dua kepentingan, yaitu karyawan sebagai individu dan perusahaan yang sangat berkepentingan terhadap kinerja dari karyawannya yang ada. Peranan karyawan merupakan faktor yang sangat menentukan dalam mencapai tujuan perusahaan. Dengan produktivitas kerja karyawan yang optimal maka pencapaian tujuan dan keberhasilan perusahaan dapat terwujud.

Secara umum dapat dikatakan bahwa kinerja merupakan ukuran keberhasilan suatu perusahaan dalam mencapai tujuan. Tujuan organisasi hanya dapat dicapai jika karyawan berupaya untuk berkinerja dengan baik. Untuk berkinerja lebih baik dibutuhkan pegawai yang memiliki loyalitas yang tinggi. Menurut Mangkunegara (2001:67); kinerja dapat didefinisikan sebagai hasil kerja secara kualitas dan kuantitas yang dapat dicapai oleh seseorang pegawai dalam melaksanakan tugas sesuai dengan tanggung jawab yang diberikan kepadanya. 
Peningkatan kinerja tentu saja tidak lepas dari faktor-faktor yang mempengaruhinya seperti sikap karyawan, perilaku karyawan dan motivasi karyawan terhadap suatu pekerjaan itu sendiri. Tanpa faktor faktor tesebut, maka pencapaian tujuan dan keberhasilan perusahaan menjadi sesuatu yang sulit bahkan mustahil. Dan perusahaan tidak mampu mencapai sasarannya.

Sikap yang baik juga menjadi salah satu faktor yang penting agar kinerja dapat berjalan secara optimal. Menurut Kartono (2000 : 297) berpendapat "sikap merupakan organisasi dari unsur-unsur kognitif, emosional dan momen-momen kemauan yang khusus dipengaruhi oleh pengalaman - pengalaman masa lampau, sehingga sifatnya dinamis dan memberikan pengarahan pada setiap tingkah laku pegawai”. Dari teori di atas maka apabila seorang karyawan dalam mengerjakan suatu pekerjaan dengan cara yang baik, mengerjakan dengan senang, penuh tanggung jawab dan tanpa paksaan, maka hasil pekerjaan yang dikerjakan akan baik dan sesuai dengan keinginan, sebaliknya apabila dikerjakan dengan terburu - buru dan dengan kondisi emosi yang tinggi maka pekrjaan akan hancur. Jadi selain keahlian sesuai dengan kompetensinya maka harus didukung dengan faktor emosi yang baik juga. Sikap dan perilaku disiplin akan muncul pada diri pribadi apabila ada suatu penekanan, penciptaan dari lingkungan dimana individu berinteraksi, terutama dalam lingkungan kerja. Disiplin kerja akan tercipta apabila suatu organisasi atau instansi menetapkan aturan dan ketetapan sesuai dengan budaya dan kesepakatan bersama, agar tujuan organisasi tercapai.
Dalam mewujudkan pegawai yang memiliki kinerja yang baik, tidak lepas dari peranan seorang pemimpin, dalam hal ini adalah atasan langsung dari seorang pegawai. Seorang pemimpin harus selalu membangkitkan dorongan kerja atau motivasi dengan menciptakan iklim kerja yang menyenangkan sehingga pegawai lebih terdorong untuk meningkatkan prestasi kerjanya. Motivasi sering diartikan sebagai pendorong agar seseorang melakukan suatu kegiatan untuk mencapai tujuannya. Jadi motivasi dapat digunakan sebagai pendorong agar seorang pegawai mau dan bersedia mengerahkan seluruh kemampuannya untuk bekerja, sehingga dengan melaksanakan pekerjaan tersebut pegawai dapat memenuhi kebutuhannya. Oleh karena itu dalam rangka memacu kinerja pegawai diperlukan adanya dorongan-dorongan atau motivasi kerja.

Madrasah Tsanawiyah Negeri (MTsN) Takeran Kabupaten Magetan merupakan institusi pendidikan keagamaan setingkat dengan Sekolah Menengah Pertama. Dalam mewujudkan tujuan organisasi, MTsN Takeran menuntut tersedianya tenaga yang profesional, untuk itu perlu adanya pegawai yang mempunyai komitmen dan dedikasi yang tinggi sehingga pelaksanaan pengembangan organisasi dapat dikerjakan secara optimal, efektif dan efisien.

Untuk itulah dalam kesempatan ini peneliti merasa tertarik melakukan penelitian dengan mengangkat judul "Pengaruh Sikap dan Motivasi terhadap Kinerja Karyawan pada MTsN Takeran Kabupaten Magetan" 
Berdasarkan latar belakang masalah sebagaimana yang telah diuraikan diatas, dapat dirumuskan permasalahan penelitian sebagai berikut:

1. Apakah Sikap berpengaruh signifikan terhadap kinerja karyawan ?

2. Apakah motivasi berpengaruh signifikan terhadap kinerja karyawan?

Tujuan dari penelitian ini adalah

1. Untuk memberikan bukti empiris mengenai pengaruh Sikap terhadap kinerja karyawan.

2. Untuk memberikan bukti empiris mengenai pengaruh Motivasi terhadap kinerja karyawan

\section{METODE PENELITIAN}

Penelitian ini dilakukan di MTsN Takeran yang beralamatkan di Jalan Raya Takeran, Desa Kuwonharjo Kec. Takeran Kab. Magetan. Adapun waktu pelaksanaan penelitian adalah tanggal 1 Agustus 2016.

Sugiyono (2013) menyatakan bahwa populasi adalah wilayah generalisasi yang terdiri atas objek atai subjek yang memiliki kualitas dan karakteristik tertentu yang ditetapkan oleh peneliti untuk dipelajari dan kemudian ditarik kesimpulannya.Sedangkan menurut Amirullah (2014) populasi dalam penelitian merupakan keseluruhan dari kumpulan elemen-elemen yang memiliki sejumlah karakteristik umum, yang terdiri dari bidangbidang untuk diteliti.

Berdasarkan beberapa uraian di atas, dapat disimpulkan bahwa populasi adalah keseluruhan objek penelitian yang dapat terdiri dari manusia, benda, hewan, tumbuhan, gejala, nilai tes, atau peristiwa, sebagai sumber data yang memiliki karakteristik tertentu dalam suatu penelitian. Dalam penelitian ini populasi yang diambil adalah seluruh karyawan MTsN Takeran Kabupaten Magetan yang berjumlah 50 orang.

Menurut Sugiyono (2013) sampel adalah bagian dari jumlah dan karakteristik yang dimiliki oleh populasi tersebut. Sedangkan menurut Amirullah (2014) sampel penelitian merupakan sub kelompok dari populasi yang dipilih untuk digunakan dalam suatu penelitian.

Berdasarkan beberapa pendapat di atas, dapat disimpulkan bahwa sampel merupakan bagian dari populasi yang mempunyai karakteristik dan sifat yang mewakili seluruh populasi yang ada.Terdapat berbagai teknik untuk menentukan jumlah sampel yang akan digunakan. Dalam penelitian ini, peneliti menggunakan teknik sampling jenuh yaitu teknik penentuan sampel dimana semua anggota populasi digunakan sebagai sampel (Sugiyono, 2013). Hal ini dilakukan karena penelitian ingin membuat generalisasi dengan kesalahan yang sangat kecil. Berdasarkan uraian tersebut, maka sampel dalam penelitian ini adalah seluruh karyawan MTsN Takeran yang berjumlah 50 orang.

Instrumen pengumpulan data pada penelitian ini adalah angket atau kuesioner. Menurut Arikunto (2006:151) angket atau kuesioner adalah pernyataan tertulis yang digunakan untuk memperoleh informasi dari responden dalam arti laporan tentang pribadi atau hal-hal yang ia ketahui.

Angket yang digunakan dalam penelitian ini adalah angket tertutup dengan kemungkinan jawaban yang 
telah tersedia. Mengenai alternatif jawaban dalam angket, penulis menggunakan skala ordinal. Menurut Sugiyono (2013) skala ordinal adalah skala pengukuran yang tidak hanya menyatakan kategori, tetapi juga menyatakan peringkat construct yang diukur.

Untuk setiap pilihan jawaban diberi skor, maka responden harus menggambarkan, mendukung pernyataan (item positif) atau tidak mendukung pernyataan (item negatif). Skor atas pilihan jawaban untuk kuesioner yang diajukan untuk pernyataan positif adalah sangat setuju (5), setuju (4), kurang setuju (3), tidak setuju (2) ,sangat tidak setuju (1).

Dalam penelitian ini digunakan Tiga variabel penelitian yaitu Sikap $\left(\mathrm{X}_{1}\right)$, Motivasi $\left(\mathrm{X}_{2}\right)$ dan Kinerja karyawan $(\mathrm{Y})$

Uji validitas dilakukan melalui analisis data Correlated-Item Total Correlationyaitu dengan cara mengkorelasikan masing-masing skor item dengan skor total dan melakukan korelasi terhadap nilai koefisien korelasi dengan dasar pengambilan keputusan Jika nilai $r_{\text {hitung }}>r_{\text {tabel }}$, maka pernyataan dalam kuesioner dinyatakan valid, sedangkan jika nilai $r_{\text {hitung }}<r_{\text {tabel }}$, maka item pertanyaan dalam kuesioner dinyatakan tidak valid. Ghozali (2013:53).

Ujireliabilitas dengan cara melihat Cronbach Alpha dengan signifikansi yang digunakan lebih besar dari 0,70. Suatu konstruk atau variabel dikatakan reliabel jika memberikan nilai Cronbach Alpha> 0,278 (Ghozali, 2013:48).

Uji asumsi Normalitas menggunakan metode KolmogrovSmirnov jika hasil angka signifikansi (Sig) lebih kecil dari 0,05 maka data tidak terdistribusi normal. Ghozali (2013:160). Uji heteroskedastisitas adalah dengan melihat grafik scatterplot antaranilai prediksi variabel terikat (ZPRED) dengan residualnya (SRESID). Dasar pengambilan keputusan uji tersebut yaitu Jika ada titik-titik yang membentuk pola tertentu yang teratur seperti bergelombang, melebar kemudian menyempit, maka mengindikasikan adanya heteroskedastisitas. Jika tidak terdapat pola tertentu yang jelas, serta titiktitik menyebar diatas dan dibawah angka nol pada sumbu $\mathrm{Y}$ maka mengindikasikan tidak terjadi heteroskedastisitas. Menurut Ghozali (2013:139).

Uji Autokorelasi dilihat dari uji DurbinWaston (DW Test). Dengan dasar pengampilan keputusan jika Du $<\mathrm{d}<4$-du maka dinyatakan tidak terdapat autokorelasi. Ghozali (2013:110) .

Uji multikolinieritas dilakukan dengan melihat nilai tolerance dan lawannya (2) variance inflation factor ( VIF ). Jika nilai tolerance yang rendah sama dengan nilai VIF tinggi ( karena $\mathrm{VIF}=1 /$ Tolerance $)$. Nilai cut off yang umum dipakai untuk menunjukkan adanya multikolinieritas adalah Nilai Tolerance $\leq 0,10$ atau sama dengan nilai VIF $\geq 10$. Ghozali (2013:105).

Teknik analisis data yang dipaki adalah regresi linier berganda (multiple regression). Untuk menguji pengaruh variabel penelitian secara parsial digunakan uji t. Dengan dasar pengambilan keputusan bila $t_{\text {hitung }}>$ $t_{\text {tabel }}$ pada $\alpha=0,05$ artinya variabel independen secara parsial mempengaruhi variabel dependen. Bila $\mathrm{t}_{\text {hitung }}<\mathrm{t}_{\text {tabel }}$ pada $\alpha=0,05$ artinya variabel independen secara parsial tidak mempengaruhi variabel 
dependen. Ghozali (2013:98).

Untuk menguji pengaruh variabel penelitian secara simultan digunakan uji $F$. Dengan dasar pengambilan keputusan bila $F_{\text {hitung }}>F_{\text {tabel }}$ pada $\alpha=0,05$ artinya variabel independen secara simultan mempengaruhi variabel dependen. Bila $F_{\text {hitung }}<F_{\text {tabel }}$ pada $\alpha=0,05$ artinya variabel independen secara simultan tidak mempengaruhi variabel dependen. Ghozali (2013).

\section{HASIL PENELITIAN DAN PEMBAHASAN}

Dari hasil spss 21.00 dihasilkan dari regresi variabel independen yaitu Sikap $\left(\mathrm{X}_{1}\right)$, Motivasi $\left(\mathrm{X}_{2}\right)$ dan Kinerja karyawan (Y)dilakukan melakukan uji regresi linier berganda. Berikut ini hasil uji regresi linier berganda

\begin{tabular}{|l|l|l|l|l|}
\hline Variabel & $\begin{array}{c}\text { Koefisien } \\
\text { Regresi }\end{array}$ & $\begin{array}{c}\text { Stan } \\
\text { dar } \\
\text { Eror }\end{array}$ & thitung & Sig \\
\hline Konstanta & 7,405 & $\begin{array}{l}2,58 \\
1\end{array}$ & & $\begin{array}{l}0,00 \\
0\end{array}$ \\
\hline Sikap $\left(\mathrm{X}_{1}\right)$ & 1,007 &, 160 & $\begin{array}{l}3,00 \\
5\end{array}$ & $\begin{array}{l}0,04 \\
2\end{array}$ \\
\hline $\begin{array}{l}\text { Motivasi }\left(\mathrm{X}_{2}\right. \\
\text { ) }\end{array}$ & 1,523 &, 112 & $\begin{array}{l}4,43 \\
7\end{array}$ & $\begin{array}{l}0,01 \\
6\end{array}$ \\
\hline $\mathrm{R}^{2}$ & 0,44 & \\
\hline Adjusted $\mathrm{R}^{2}$ & 0,507 & \\
\hline$F_{\text {hitung }}$ & 1.201 & Sig : 0,000 \\
\hline $\mathrm{N}$ & 50 &
\end{tabular}

Berikut adalah persamaan regresi linier berdasarkan hasil analisisi di atas:

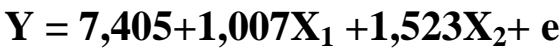

Berdasarkan persamaan di atas dapat dijelaskan bahwa Kinerja Karyawan pada MTsN Takeran sebelum ada variabel Sikap dan Motivasi adalah sebesar 7,405. Variabel Sikap memberikan kontribusi sebesar 1,007 artinya setiap ada kenaikan 1 satuan dari variabel Sikap akan berpengaruh pada peningkatan Kinerja Karyawan sebesar 1,007. Variabel Motivasi memberikan kontribusi sebesar 1,523 artinya setiap ada kenaikan 1 satuan dari variabel Motivasi akan meningkatkan Kinerja Karyawan sebesar 1,523 .

Pada penelitian ini diketahui nilai t-hitung adalah 3,005 dengan nilai signifikansi 0,042 . Nilai $t_{\text {tabel }}$ pada taraf signifikansi 0,05 dengan jumlah $\mathrm{n}=50$ adalah 1,675. Berdasarkan data di atas diketahui bahwa nilai $t_{\text {hitung }}$ $3,002>t_{\text {tabel }} 1,675$ dan nilai signifikansi $0,042<0,05$ menunjukkan bahwa terdapat pengaruh positif antara Sikap terhadap kinerja karyawan MTsN Takeran .

Dari hasil pengujian dapat diketahui bahwa sikap kerja secara parsial berpengaruh positif terhadap kinerja karyawan, hal ini berarti bahwa semakin baik sikap kerja yang dimiliki oleh karyawan maka diharapkan kinerja karyawan akan semakin meningkat. Fenomena ini membuktikan bahwa pentingnya masalah sikap sering dikaitkan dengan perilaku atau perbuatan manusia dalam kehidupan sehari-hari. Sikap yang ada pada diri seseorang akan memberikan warna atau corak pada perilaku atau perbuatan orang yang bersangkutan. Dengan adanya sikap kerja karyawan yang baik terhadap perusahaan, maka akan mendorong karyawan untuk bekerja lebih baik lagi (Dongoran, 2006). Sehingga dapat disimpulkan bahwa variabel Sikap Kerja dapat digunakan sebagai dasar untuk mengukur tingkat kinerja karyawan.

Hasil selanjutnya menunjukkan nilai $t_{\text {hitung }}$ sebesar 4,437 dengan nilai signifikansi 0,016 . Nilai $t_{\text {tabel }}$ pada taraf signifikansi 0,05 dengan jumlah $n=45$ adalah 1,675. Berdasarkan data di atas diketahui bahwa nilai $t_{\text {hitung }} 5,427>t_{\text {tabel }} 1,675$ dan nilai signifikansi $0,016<0,05$ 
menunjukkan bahwa ada pengaruh positif dan signifikan antara motivasi terhadap kinerja karyawan MTsN Takeran Magetan

Berdasarkan hasil penelitian sebelumnya oleh Mega Sukma Manggarsari pada PT. Patrinsaka Gempol - Pandaan Pasuruan membuktikan bahwa Sikap Kerja dan Motivasi Kerja berpengaruh positif terhadap Kinerja Karyawan pada PT. Patrinsaka Gempol - Pandaan, Pasuruan, hal ini berarti bahwa semakin baik Sikap Kerja, Motivasi Kerja dan Komitmen Organisasi, maka diharapkan kinerja Karyawan pada PT. Patrinsaka Gempol Pandaan, Pasuruan, akan semakin baik. fenomena membuktikan bahwa perilaku individu sebagai karyawan dapat dilihat dari kemampuan kerjanya, motivasinya, inisiatifnya, kreativitasnya dan lainnya yang dapat mempengaruhi prestasi kerjanya. Kinerja karyawan dapat mencapai kondisi yang diharapkan apabila setiap pegawainya dalam kondisi fisik dan mental yang baik. Dari hasil penelitian ini juga menunjukkan bahwa perubahan yang terjadi pada variabel kinerja karyawan sebesar $50,7 \%$ dipengaruhi oleh variabel Sikap Kerja dan Motivasi sehingga dapat disimpulkan bahwa Sikap Kerja dan Motivasi Kerja dapat digunakan sebagai dasar untuk mengukur tingkat kinerja karyawan.

Dalam hal pengendalian Sikap MTsN Takeran menggunakan metode pendekatan. Cara tersebut bisa menjadi pilihan yang "luwes" dan sederhana untuk mengubah kebiasaan sikap yang buruk menjadi kebiasaan yang menguntungkan bagi lingkungan Sekolah, dan tentu saja bagi dirinya sendiri. Kebanyakan pihak HRD atau psikolog dalam suatu perusahaan mudah yakin dengan alat tes psikologi yang diselenggarakan pada saat rekrutmen padahal alat tersebut hanya memberikan pengungkapan yang belum tentu akurat. Bisa saja pegawai tersebut bekerja dengan semangat dan senyum padahal pikiran dan perasaannya tidak mencerminkan apa yang dia tunjukkan. Mengetahui lebih mendalam pikiran, perasaan, keinginan, dan keperluannya dengan berinteraksi menjalin hubungan yang dekat menciptakan rasa kekeluargaan antar pegawai itu menjadi dasar yang kuat dalam membina Sikap dan karakter yang baik bagi semua karyawan MTsN Takeran Kabupaten Magetan.

Pemberian motivasi kerja
yang dilakukan MTsN Takeran Kabupaten Magetan dilakukan dengan memperhatikan dan memenuhi kebutuhan-kebutuhan dari para karyawannya yang meliputi kebutuhan fisiologi, keamanan, sosial, penghargaan dan aktualisasi diri. Seperti memberikan imbalan serta perhatian yang lebih, sesuai dengan hasil kerja yang berhasil dicapai oleh karyawan, misalnya dengan kenaikan gaji, pemberian jaminan keselamatan serta perhatian terhadap kenyamanan kerja, kesempatan membina hubungan yan baik dalam bekerja, serta kesempatan yang lebih baik untuk dapat meningkatkan keterampilan dan keahlian dalam karir mereka. Sehingga tercipta rasa puas dan nyaman dalam menjalankan aktivitas kerja karena semua karyawan merasa saling menghargai dan saling termotivasi dalam meningkatkan kinerjanya masingmasing.

\section{KESIMPULAN}

Kesimpulan dari penelitian ini adalah sebagai berikut 
Berdasarkan persamaan regresi dalam penelitian ini, maka dapat diketahui bahwa variabel Sikap mempunyai pengaruh yang positif terhadap Kinerja Karyawan MTsN Takeran Kabuparen Magetan. Artinya apabila Sikap kerja semua karyawan baik atau mampu mengendalikan perilaku, emosional serta sikap karyawan yang mampu mengendalikan diri masing masing maka, kinerja karyawan akan meningkat.

Hasil selanjutnya dari penelitian ini menunjukkan bahwa variabel Motivasi mempunyai pengaruh yang signifikan terhadap kinerja karyawan. Motivasi dapat meningkatkan hubungan yang harmonis terhadap semua karyawan, karena dengan dorongan motivasi mampu meningkatkan semangat karyawan sehingga berpengaruh positif terhadap kinerja karyawan pada MTsN Takeran Kabupaten Magetan.

\section{DAFTAR PUSTAKA}

Alim, M. B. 2009. Teori Herzberg dan Kepuasan Kerja Karyawan.Islam danUmmatnya. Jakarta : Raja Grafindo Persada

As'ad. Moch. 1998. Psikologi Industri. Liberty, Yogyakarta.

Crant, J. M. 2000. Proactive behavior in organizations. Journal of Management,26: $435-$ 462.Elexmedia Komputindo. Jakarta.

Crant, J. M., \& Bateman, T. S. 2000. Charismatic leadership viewed from above: The impact of proactive personality. Journal of Organizational $-\mathrm{An}$ Experiental Approach. Singapore: McGraw-Hill.

Handoko T. Hani, 2000, Manajemen Personalia dan Sumberdaya Manusia, Edisi II, Cetakan Keempat Belas, Penerbit BPFE, Yogyakarta.
Universitas Pendidikan Ganesha, Jurusan Manajemen, Volume 2 Tahun 2014.

Chapra, Umer.2000.Sistem Moneter Islam. Jakarta: Gema Insani

Cordes, C. L. dan Dougherty, T. W. 1993. A Review Izquierdo, L. G., Moreno, B. dan Izquierdo, M.G. 2010. Applying Information Theory to Small Groups Assessment : Emotions and WellBeing at Work. The Spanish Journal of Psychology, Vol. 13 No. 1, pp. 309-328

Ghozali, I.2005. Aplikasi Analisis Multivariat dengan Program SPSS. Semarang:Badan Penerbit Universitas Diponegoro

Gibson. 2008. Manajemen Sumber Daya Manusia, Edisi Keempat, Erlangga, Jakarta.

Gomes, Faustino Cardoso. 2003. Manajemen sumber daya 
manusia. Yogyakarta: Andi Sagala, Syaiful. 2009. Budaya Offset. Organisasi Kajian Konsep dan Implementasi. Yogyakarta:

Handoko T.H. 2008. Manajemen Personalia dan Sumber Daya Manusia. Edisi ke-2., BPFE, Yogyakarta.

Universitas Atma Jaya

Soerjono Soekanto. 2001. Sosiologi. Jakarta:PT Rajagrafindo Persada.

Kaloh. DR. J. 2006. Pemimpin Antara Keberhasilan dan Kegagalan. Jakarta:Kata Hasta Pustaka.

Kartini Kartono. 2006. Pemimpin dan kepemimpinan. Jakarta: PT. Rajagrafindo Persada

Mahmudi. 2005. Manajemen Kinerja Sektor Publik. Yogyakarta: UPP AMP YKPN.

Marihot Tua, Effendi Hariandja. 2002. Manajemen Sumber Daya Manusia. Jakarta: Grasindo.

Mathis, Robert L dan Jackson, John H, 2002. Manajemen Sumber Daya Manusia, Buku ke dua. Jakarta: Salemba Empat

Rivai Veithzal \& Ahmad Fawzi Mohd Basri. 2004. Performance Appraisal Sistem Yang Tepat Untuk Menilai Kinerja Karyawan Dan Meningkatkan Daya Saing Perusahaan. Jakarta : PT. Raja Grafindo Persada

Riniwati, Harsuko. 2011. Mendongkrak Motivasi dan Kinerja: Pendekatan Pemberdayaan SDM. Malang: UB Press

Robbins, Stephen P. 2001. Perilaku Organisasi, Jilid 1. Jakarta; Pt.Prenhallindo.

Siagian, Sondang P. 2007. Manajemen Sumber Daya Manusia, Bumi Aksara. Jakarta.

Simamora, H., 1995. Manajemen Sumber Daya Manusia Edisi Kedua. STIE YKPN, Yogyakarta.

Simanjuntak Payaman J. 2005. Manajemen dan Evaluasi Kinerja. Jakarta: Lembaga Penerbit Fakultas Ekonomi UI

Sinambela, Lijan. (2012). Kinerja Pegawai: Teori, Pengukuran dan Implikasi. Yogyakarta: Graha Ilmu. 
[Type text] 